\title{
各種ショックに対する Methylprednisolone
}

\section{Sodium Succinate の臨床効果}

—二重盲検法による Hydrocortisone

Sodium Succinate との比較 —

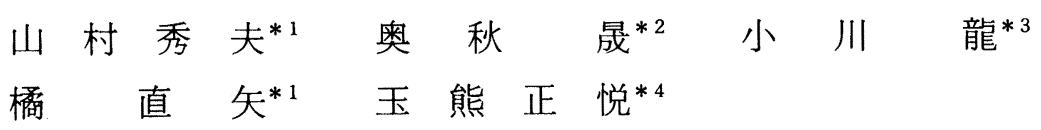

（受付：1980年 5 月 26 日）

A Double Blind Controlled Study on the Clinical Effects of Methylprednisolone Sodium Succinate in Shock as Compared with Hydrocortisone Sodium Succinate

Hideo YAMAMURA*1 ${ }^{* 1}$ Akira OKUAKI*2, Ryu OGAWA*3, Naoya TACHIBANA*1 and Shoetsu TAMAKUMA*4

*1 Department of Anesthesiology, Faculty of Medicine, University of Tokyo

*2 Department of Anesthesiology, Fukushima Medical College

*3 Department of Anesthesiology, School of Medicine, Gunma University

${ }^{*}$ Department of First Surgery, Faculty of Medicine, University of Tokyo

The effects of methylprednisolone sodium succinate (Solu-Medrol ${ }^{\circledR}$ ) in shock were studied by the double blind technique at 32 medical centers, using hydrocortisone sodium succinate (Solu-Cortef ${ }^{\circledR}$ ) as the active control drug. Either methylprednisolone sodium succinate or hydrocortisone sodium succinate was administered in an initial dose of $20 \sim 30 \mathrm{mg}$ per $\mathrm{kg}$ of body weight to each of 135 patients. Any patients who failed to respond well to the initial doses were given additional doses. The effects of the steroids used were evaluated within 12 hours following the final doses.

The results obtained are as follows:

*1 東京大学医学部麻酔科

(現在:日本専壳公社東京将院

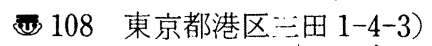

*2 福島県立医科大学麻酔科

*3 群馬大学医学部麻酔科

*4 東京大学医学部第一外科 
1. The general improvement rate was higher for the methylprednisolone sodium succinate group than for the hydrocortisone sodium succinate group.

2. The global utility rate was greater for the methylrednisolone sodium succinate group than for the hydrocortisone sodium succinate group.

3. Methylprednisolone sodium succinate group showed a greater improvement than the hydrocoritsone sodium succinate group in the post-treatment measurements of shock score, systolic blood pressure, pulse pressure, shock index, urinary output, arterial blood $\mathrm{pH}$ and Base Excess.

Key words : shock, methylprednisone sodium succinate, hydrocortisone sodium succinate, shock score, systolic blood pressure, pulse pressure, shock index, arterial blood pH, Base Excess

はじめに

ショックとは組織環流の急激な低下による細胞 機能の障害に起因する臨床症候群であり, ショッ ク状態が遷延すると細胞損傷がすすみ, 極めて予 後不良となる. ショックの治療は循環動態の改善
をもって第一とするが，細胞損傷の予防の目的で 副腎皮質ステロイドの投与が行われている. ショックに対する副腎皮質ステロイドの臨床効果 は Weil ら ${ }^{1)}$ Schumer らの研究によって確認 され，現在では短期大量療法がその主流である. 合成副腎皮質ステロイドである methylpredni-

Tab. 1 Solu-Medrol (ショック) 研究会

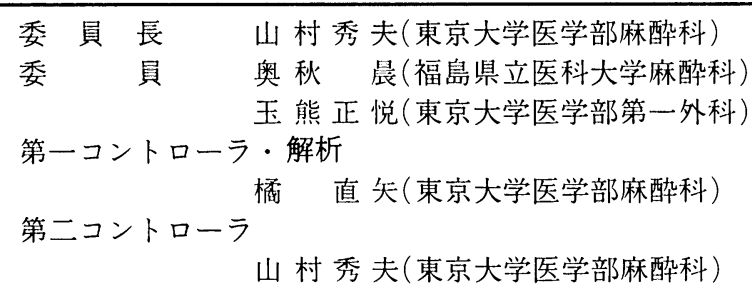

臨床試験実施施設（順不同）

札幌医科大学第一外科

弘前大学医学部麻酔科

青森県立中央病院麻酔科

東北大学医学部麻酔科

福島県立医科大学麻酔科

群馬大学医学部麻酔科

前橋赤十字病院麻酔科

東京大学医学部第一外科

帝京大学医学部麻酔科

順天堂大学医学部麻酔科

昭和大学医学部外科

東邦大学医学部救急センター

中央鉄道病院麻酔科

東京厚生年金病院麻酔科

東京厚生年金病院外科

横浜市立大学医学部麻酔科
横浜市立大学医学部第二外科

聖マリアン十医科大学第一外科

名古屋市立大学医学部麻酔科

京都府立医科大学麻酔科

京都府立医科大学第二外科

市立京都病院麻酔科

大阪大学医学部 I C U

大阪赤十字病院 I C U

関西医科大学外科

岡山大学医学部麻酔科

倉敷中央病院麻酔科

福岡大学医学部麻醉科

福岡中央病院外科

熊本大学医学部第二外科

熊本大学医学部 I C U

荒尾市民病院外科 
solone は強い抗ショック作用を有するため, 欧米 に拈いて好んで用いられている31 5).一方, 我国に 拈いては hydrocortisone がショックに対して広 く用いられている.これら methylprednisolone と hydrocortisone の抗ショック効果に関する厳 密な臨床試験はなされていない，そこで本研究に 颃いて, methylprednisolone sodium succinate hydrocortisone sodium succinate の各種ショッ クに対する臨床効果を比較するため二重盲検試験 を行った。この実験を実施するにあたり研究会を 組織し, 委員会 (Tab. 1) で臨床試験方法, 調査表 等を検討し決定した。

\section{試験方法}

\section{1. 試験実施施設}

本試験は全国の 32 施設で行われた. それらの施 設名は Tab. 1 に示す.

2. 対象, 症例数, 試験期間, 除外基準, 脱落 基準

昭和 54 年 1 月より同年 10 月まで上記施設で治 療を受けた 15 歳以上のショック患者を対象とし て 160 例を収集目標とした.ショックの診断基準 は小川 ${ }^{6)}$ の提唱するショック・スコア法（後に説 明）に従い 6 点以上とした。

a. 除外基準

(1)ショック・スコアが 5 点以下の症例

(2) 15 歳未満の小児

(3)既に, ショック治療の目的で副腎皮質ステロ イドが投与された症例

(4)その他, 委員会が除外症例と判定した症例

b. 脱落基準

(1)ショック・スコアを算出する必須 5 項目（収 縮期血圧, 脈拍数, 時間尿量, Base Excess, 意識) の測定がなされなかった症例

(2)その他, 委員会が脱落症例と判定した症例 ただし、除外および脱落症例の判定は key code 開封前に委員会で決定した。

\section{3. 試験薬剂}

a. 対照薬

Hydrocortisone sodium succinate (Solu-Cor- tef $\left.^{\circledR}\right)$; 以下 $\mathrm{HC}$ と略す.

\section{b. 被験薬}

Methylprednisolone sodium succinate(SoluMedrol $^{\circledR}$ ); 以下 MP と略す.

$\mathrm{HC}$ 扎よび MP はそれぞれ $500 \mathrm{mg}$ を封入した バイアルと添付溶解用液 $8 \mathrm{ml}$ を封入したバイア ルを 1 包装とし, 10 包装を 1 症例分として試験番 号を付記した。試験薬执よび溶解用液に対する視 覚, 嗅覚等の感覚検査でコントローラが識別不能 を確認した．薬剤試験は，コントローラが無作為 に抽出したものを慶応義塾大学病院薬局製剂課 （佐々木 隆，他）で実施した。 その結果, 平均 含有量は HC 100.1\%, MP 101.5\% で, 規格に適合 し, また, 両薬剤間での識別不能が確認された。

\section{4. 割り付けと投与方法}

割り付けはコントローラが電算機の発生する乱 数表に基づき 4 例をブロックとして割り付けを し，各施設に 4 例を 1 組として配布した.

$\mathrm{HC}$ 抌よび MP ともにショックの診断が行わ れた対象患者に $20 \sim 30 \mathrm{mg} / \mathrm{kg}$ を緩徐に, 静注ま たは点滴静注した. 投与後, 患者の状態を観察し ショックの充分な改善が認められない時は適宜追 加投与した.

\section{5. 併用療法}

$\mathrm{HC}$ あるいは $\mathrm{MP}$ 以外の副腎皮質ステロイド 剤の併用は禁止した。 その他の併用療法は, 主治 医が必要と認めたあらゆる治療に制限を加えな かった。

\section{6. 評価時期}

$\mathrm{HC}$ あるいは $\mathrm{MP}$ の最終投与時より $12 \mathrm{hr}$ 以内 に評価した。

\section{7. 効果判定}

統一された調査表を配布して対象患者の全身状 態を経時的に記入した。

(1)全般改善度（ショック・スコア法による効果 判定)

ショックの重症度を客観的かつ定量的に評価す るためショック・スコア法を採用した. Tab. 2 の ように収縮期血圧, 脈拍, 時間尿量, Base Excess, 意識状態をとりあげ 4 段階に評価して点数を付与 
Tab. 2 ショック・スコア

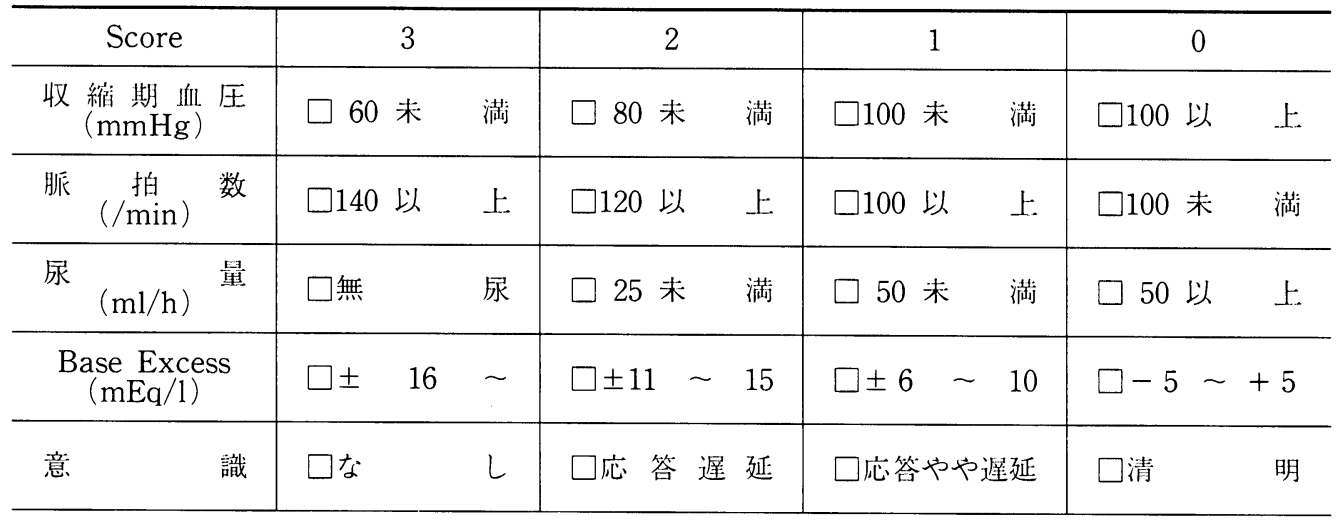

しその合計をショック・スコアとした。この ショック・スコアの改善の程度から次のように治 療効果を判定した。

(1)著効：ショック・スコアが 2 点以下になった 場合

(2)有効：ショック・スコアが正常域である 5 点 以下となった場合

(3)やや有効：ショック・スコアが 1 点以上減少 した場合

(4)不変：ショック・スコアが不変の場合

(5)悪化：ショック・スコアが増加した場合

(2)臨床検査値による効果

調査表にみられる血圧，脈拍数等の物理的診断 や生化学的検査の変化を分析し, $\mathrm{HC}$ と $\mathrm{MP}$ の間 で比較した。

\section{8. 副作用}

HC および MP によると考えられる副作用は 積極的に記載した.

\section{9。主治医の主観による有用性の判定}

試験担当医が主観に基づき投与した被験薬また は対照薬の有用性を次のように評価した。

(1)極めて有用，(2)かなり有用，(3)やp有用，(4) 有用とは思わない，(5)やや好ましくない，(6)かな り好ましくない，(7)極めて好ましくない。

\section{0. 解析方法}

解析は次の方法によった。

(1)年齢，体重，薬剤の投与量の検定は対応なし の $\mathrm{t}$ 検定で行った.
(2)全般改善度, 有用度の分布は Wilcoxon 2 標 本検定, 臨床検査值, ショック・スコアは $\mathrm{t}$-検定 で行った（ただし，群内前・後差比較には paired $\mathrm{t}$-検定).

(3)性別，薬剂投与方法，ショックの種類別症例 数, 併用薬剂の使用率, 全般改善度, 死亡率, 副 作用発現率, 有用率は $x^{2}$ 検定で行った.

\section{試験結果}

\section{1. 症例の選択}

投薬の行われた症例は 172 例であった. Key code 開封前に委員会が各症例の調査表を検討し て除外扣よび脱落症例を決定した。その結果，除 外・脱落症例は 37 例 (21.5\%) であり, 解析に供 せられた症例は 135 例（78.5\%）となった. 135 例 の内訳は $\mathrm{HC}$ 投与群 (以下 $\mathrm{HC}$ 群とする) 67 例, MP 投与群 (以下 MP 群とする) 68 例であった. また, 除外例は $\mathrm{HC}$ 群 14 例, MP 群 19 例, 脱落 例は HC 群 2 例, MP 群 2 例であった。

\section{2. 背景因子}

\section{a . 患者の特性}

$\mathrm{HC}$ 群と MP 群の性別, 年龄, 体重のいずれに も 2 群間に差を認めなかった。 また患者をショッ クの原因別に出血性ショック, 敗血症性ショック, 心原性ショックおよびその他のショックに分類し たが， 2 群間でショックの種類別症例数に差は認 められなかった。

b. 投与前値 
ショック・スコアの投与前値は $\mathrm{HC}$ 群 $8.3 \pm 2.0$ (Mean \pm S. D.), MP 群 8.7 2 2.3 であり, 2 群間に 差は認められなかった.

\section{C. 治療薬剤}

(1)HC および MP の用法・用量

$\mathrm{HC}$ の投与方法としては, 緩徐な静注が 56 例, 点滴静注が 11 例であった. MP ではそれぞれ 53 例, 15 例であり，両群間に差は認められなかった。 1 回投与の及の症例は HC 群 33 例, MP 群 38 例 で, 追加投与を必要とした症例はそれぞれ 34 例, 30 例であり, 最高投与回数は HC 群が 5 回, MP 群が 6 回であった. 総投与量は HC 群 2060.4土 $1142.4 \mathrm{mg}$ (Mean \pm S. D.), MP 群は 1920.6土 $1180.7 \mathrm{mg}$ で群間差は検出しなかった。

(2)併用薬剤

ショックという特殊状況下であるため, 試験薬 剂である $\mathrm{HC}$ あるいは MP 以外の副腎皮質ステ ロイド斉の併用のみを制限した，両群とも全例に 何らかの併用薬を用いていたが，併用薬の使用状 況に差は認められなかった.

\section{3 . 治療効果}

背景因子の項目の検討より，2 群は同一母集団 からの無作為抽出として試験に組み込まれたと判 断して以下に述べる解析を実施した. a、全般改善度（ショック・スコアによる効果 判定)

ショック・スコアによって評価した結果は Tab. 3 に示す. ショック全体についての分布で両 剂の分布間差を検定すると有意ではない（Wilcoxon 2 標本検定, $\mathrm{t}=1.5128, \mathrm{p}>0.1)$. しかし単純 有効率を検討すると, “著効”, “有効”を併せた単 純有効率は, HC 群 $62.7 \%, \mathrm{MP}$ 群 $72.1 \%$ で, 2 剂間には有意差がなかったが，ショック・スコア に怙いて 1 点以上の改善を認めた “やや有効”を 併せると, MP 群の方が有意に優れていた。

b. 臨床検査値による効果

収縮期血圧, 脈圧, 脈拍数, 時間尿量, Base Excess, 動脈血 $\mathrm{pH}$ 等は一般にショックが改善す るにつれて変化を示す.

$\mathrm{HC}, \mathrm{MP}$ 投与前後の変化扣よび, 両薬剂間で投 与前・後の比較をした (Tab. 4).

(1)ショック・スュア

$\mathrm{HC}$ 群, MP 群とも, 投与前值に比し投与後で は有意に改善した。また，両群間の比較では，投 与前には差は認められなかったが，投与後では MP 群が HC 群に比し有意に改善した。

(2)収縮期血圧

投与前値で, 収縮期血圧が低く過ぎ, 血圧測定 が不能であった症例が HC 群に 2 例, MP 群に 1

Tab. 3 全般改善度

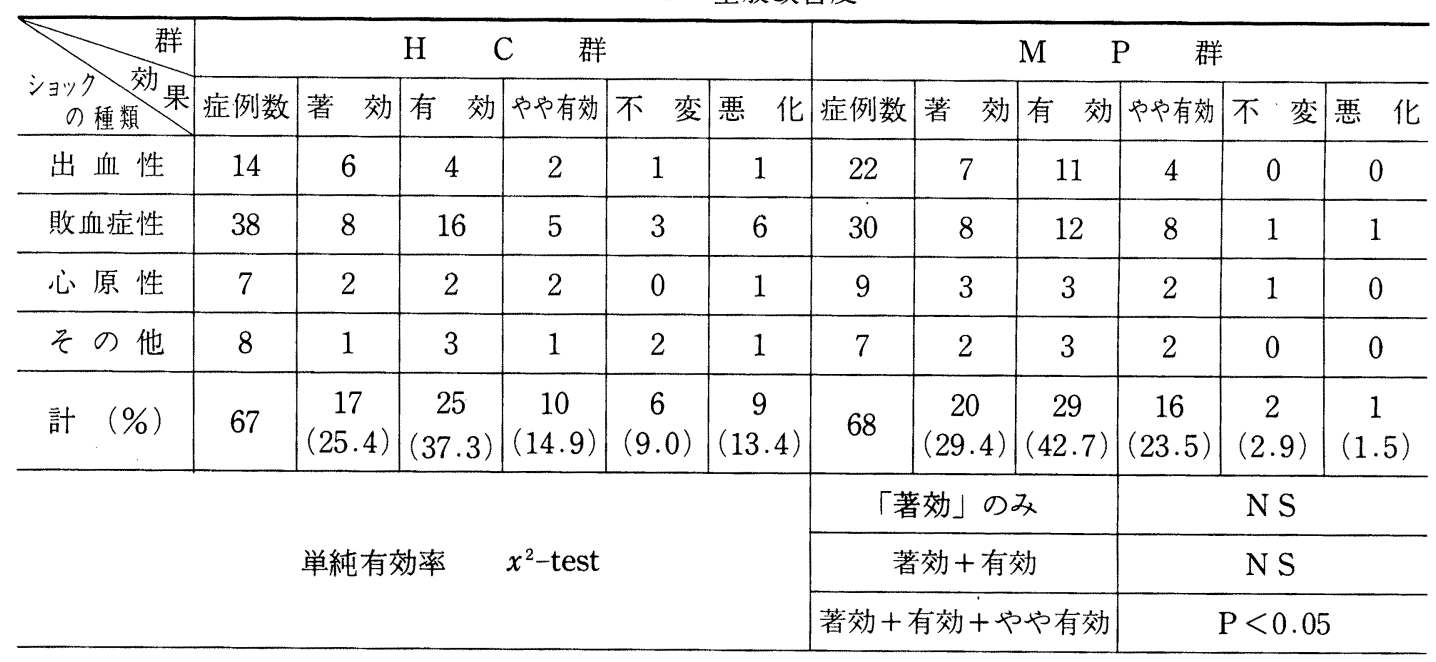


Tab. 4 ショック・スコア括よび臨床検査值による効果判定

\begin{tabular}{|c|c|c|c|c|c|c|c|c|}
\hline \multirow{2}{*}{\multicolumn{2}{|c|}{ 臨床検查 }} & \multicolumn{3}{|c|}{ H C 群 } & \multicolumn{3}{|c|}{ MP群 } & \multirow{2}{*}{ HC群vsMP群 } \\
\hline & & 症例数 & Mean \pm S.D. & 前vs後 & 症例数 & Mean \pm S.D. & 前vs後 & \\
\hline \multirow{2}{*}{ ショック・スコア } & 前 & 67 & $8.3 \pm 2.0$ & \multirow{2}{*}{$* * *$} & 68 & $8.7 \pm 2.3$ & \multirow{2}{*}{$* * *$} & N S \\
\hline & 後 & 67 & $5.2 \pm 3.3$ & & 68 & $4.2 \pm 2.8$ & & $* * *$ \\
\hline \multirow{2}{*}{$\begin{array}{c}\text { 收 䌖 期 血圧 } \\
(\mathrm{mmHg})\end{array}$} & 前 & 65 & $82.9 \pm 28.5$ & \multirow{2}{*}{$* * *$} & 67 & $74.3 \pm 26.5$ & \multirow{2}{*}{$* * *$} & NS \\
\hline & 後 & 66 & $99.5 \pm 28.3$ & & 68 & $114.4 \pm 25.3$ & & $* *$ \\
\hline \multirow{2}{*}{ 脈 $(\mathrm{mmHg})^{\text {圧 }}$} & 前 & 49 & $31.3 \pm 16.8$ & \multirow{2}{*}{$* * *$} & 45 & $27.5 \pm 12.4$ & \multirow{2}{*}{$* * *$} & N S \\
\hline & 後 & 58 & $38.9 \pm 16.0$ & & 60 & $47.7 \pm 18.1$ & & * \\
\hline \multirow{2}{*}{ 脈 $\underset{(/ \mathrm{min})}{\text { 拍 }}$ 数 } & 前 & 67 & $122.5 \pm 28.6$ & \multirow{2}{*}{$* * *$} & 68 & $120.8 \pm 28.2$ & \multirow{2}{*}{$* * *$} & N S \\
\hline & 後 & 67 & $106.9 \pm 22.5$ & & 68 & $104.0 \pm 19.2$ & & N S \\
\hline \multirow{2}{*}{ Shock Index } & 前 & 65 & $1.7 \pm 0.7$ & \multirow{2}{*}{$* * *$} & 67 & $1.8 \pm 0.9$ & \multirow{2}{*}{$* * *$} & N S \\
\hline & 後 & 66 & $1.2 \pm 0.6$ & & 68 & $1.0 \pm 0.4$ & & $* *$ \\
\hline \multirow{2}{*}{ 尿 $(\mathrm{ml} / \text { hour })^{\frac{\text { 量 }}{}}$} & 前 & 67 & $25.0 \pm 47.8$ & \multirow{2}{*}{$* * *$} & 68 & $35.6 \pm 83.3$ & \multirow{2}{*}{$* * *$} & N S \\
\hline & 後 & 67 & $60.8 \pm 57.6$ & & 68 & $99.3 \pm 138.2$ & & * \\
\hline \multirow{2}{*}{$\begin{array}{c}\text { Base Excess } \\
(\mathrm{mEq} / \mathrm{l})\end{array}$} & 前 & 67 & $-5.6 \pm 7.3$ & \multirow{2}{*}{${ }^{*}$} & 68 & $-6.1 \pm 9.4$ & \multirow{2}{*}{$* * *$} & N S \\
\hline & 後 & 67 & $-3.6 \pm 6.6$ & & 68 & $-0.6 \pm 7.5$ & & $*$ \\
\hline \multirow{2}{*}{ 動 脈 血 $\mathrm{pH}$} & 前 & 64 & $7.3 \pm 0.1$ & \multirow{2}{*}{ N S } & 68 & $7.3 \pm 0.2$ & \multirow{2}{*}{$* * *$} & N S \\
\hline & 後 & 64 & $7.3 \pm 0.1$ & & 65 & $7.4 \pm 0.1$ & & $* *$ \\
\hline
\end{tabular}

$* \mathrm{P}<0.05$

** $\mathrm{P}<0.01$

*** $\mathrm{P}<0.001$

例あり，これらを除いて検討した。両群とも投与 前に比し投与後では有意に上昇した。 また両群間 の比較では投与前には差は認められなかったが, 投与後では MP 群が HC 群に比し有意に高值に 上昇した。

(3)脈圧

両群とも有意に増大を認めた。 また，両群間の 比較では，投与前には差は認められなかったが， 投与後では MP 群が $\mathrm{HC}$ 群に比し有意に増大し た.

\section{(4)脈拍数}

両群とも有意に頻脈の改善を認めたが，両群間 には差が認められなかった。

(5) Shock Index
Allgöwer ら゙は脈拍数を収縮期血圧で除した 值をShock Index とし, ショックが改善すると Shock Index も減少するとしている. 両群とも投 与後で有意に減少した。 また, 両群間では投与前 で差は認めなかったが，投与後で，HC 群に比し MP 群が有意に減少した。

\section{(6)時間尿量}

両群とも投与後で有意に時間尿量の増加を認め た. また両群間の比較では, 投与前に差は認めら れなかったが, 投与後では MP 群が $\mathrm{HC}$ 群に比し 有意に増加した。

\section{(7) Base Excess}

両群とも投与後で有意に改善したが, MP 群の み正常範囲 ${ }^{8)}(-2.2 \sim+1.2)$ へ回復した。 また, 


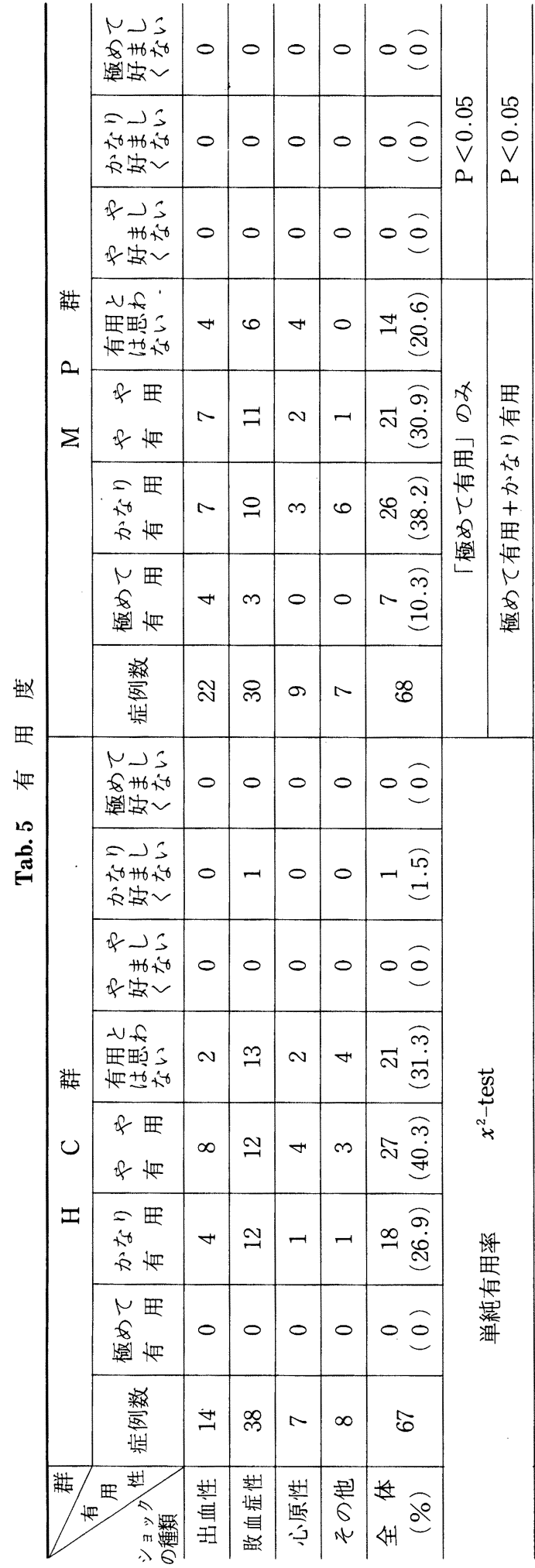

両群間の比較では投与前で差はなかったが，投与 後では HC 群に比し MP 群が有意に改善した.

(8)動脈血 $\mathrm{pH}$

$\mathrm{HC}$ 群は投与前後で有意な改善を認めなかった が，MP 群は有意の改善を認め, しかも正常範囲 内 $^{8)}$ (7.37〜 7.46) へ回復した. また, 両群間の比 較では，投与前に差は認めなかったが，投与後で は HC 群に比し MP 群が有意に回復した。

(9)その他の検査値

ショックは重症な病的状態にある為, 当然臨床 検査異常值が考兄られるが, 治療前後で検査した 症例について検討した結果, 白血球数, 血小板数, ヘモグロビン，へマトクリット，血清電解質 $(\mathrm{Na}$, $\mathrm{K}, \mathrm{Cl}, \mathrm{Ca}), \mathrm{GOT}, \mathrm{GPT}$, 血糖, BUN には有意の 変化は認められなかった.

\section{C. 転帰}

生存例は $\mathrm{HC}$ 群 23 例 (34.3\%), MP 群 27 例 （39.7\%）で，ショック状態を脱し得たが原疾患 で死亡した例は，HC 群 24 例 (35.8\%), MP 群 23 例 (33.8\%), ショックによる死亡例は HC 群 20 例 (29.9\%), MP 群 18 例（26.5\%）であり, それぞれに有意差は認められなかった。

d. 副作用

HC あるいは MP によると思われる副作用と 乙て消化性潰瘍 ( $\mathrm{HC}$ 群 2 例, MP 群 1 例), 血圧 下降 (HC 群 1 例, MP 群 1 例), 糖尿 (HC 群 3 例，MP 群 2 例）が報告されたが，両剂間に差は 認められなかった。 また, 脱落症例に HC 群で消 化性潰瘍が 1 例, 除外症例の MP 群に消化性潰瘍 2 例, 糖尿 2 例が報告され，これらを含めて比較 しても両群間に差は認められなかった.

\section{e. 有用度}

主治医が主観的評価による有用度の判定を行 なった (Tab. 5). ショック全体での有用度分布の 両剤間差を検定すると, 有意 (Wilcoxon 2 標本検 定, $\mathrm{t}=2.8020, \mathrm{p}<0.01)$ であった. さらに単に単 純有用率を検討すると，“極めて有用”之“かなり 有用”を併せた単純有用率は, HC 群の $26.9 \%$ に 対し, MP 群は 48.5\% と有意に優れていた(Tab. $5)$. 


\section{考 察}

ショックは極めて重症かつ予後不良の症候群で あり, 薬剤の効果を厳密な臨床試験で調査するに は多くの問題点がある. 事実, ショックに対する 副腎皮質ステロイドの効果についても批判に耐え 得る臨床研究は多くない。その理由として, (1) ショックの定義があいまいである，(2)明確な診断 基準が存在しない, (3)ショックの定量的把握が困 難である, (4)疾患の性質上二重盲検法が行い難い, 等があげられる.

本委員会は以上の諸点を考慮して，ショックの 診断扣よび定量的評価法としてショック・スコア 法を採用し，二重盲検法の対照薬は我国で副腎皮 質ステロイド剤として標準的ショック治療薬剤 である hydrocortisone を用いた。 また各施設の ショック治療法の違いを考慮して多施設間の共同 研究とした. そのため 135 例といら多くの症例を 得て MP の効果を解析することが出来た. 解析の 結果 $\mathrm{HC}$ 群と MP 群の間では, 次に述べる差が認 められた。

(1) “著効”, “有効”, “やや有効”を併せた単純有 効率は, MP 群の方が $\mathrm{HC}$ 群より有意に優れてい た.

（2）“極めて有用”と“かなり有用”を併せた単 純有用率は, MP 群の方が $\mathrm{HC}$ 群より有意に優れ ていた。

(3)治療によるショック・スコア，収縮期血圧， 脈圧, Shock Index, 時間尿量, Base Excess, 動 脈血 $\mathrm{pH}$ の改善の程度は MP 群の方が $\mathrm{HC}$ 群よ り有意に優れていた。

ショックに対する副腎皮質ステロイドの有効性 の機序には諸説があるが，(1)循環動態の改善, (2) ライゾゾームの安定化, (3)補体活性化の抑制, (4) 代謝の改善等が主たる作用と考えられている ${ }^{91}$ 12). これらの抗ショック作用は, 薬理学的投与量 によって発揮されるものであり，MP の 20〜30 $\mathrm{mg} / \mathrm{kg}$ 投与は各種ショックに対し有用であると 考えられる.

\section{まとめ}

全国 32 施設の協力を得て, 各種ショックに対す る MP の臨床的効果を検討するための二重盲検 試験を行った. 対照薬として HC を採用した。 ントローラの割り付けに従い, ショック患者 （ショック・スコアで 6 点以上） 135 例に 2 薬剤 のいずれかの $20 〜 30 \mathrm{mg} / \mathrm{kg}$ を初回投与した. そ して充分な改善がみられなければ適宜追加投与し た.最終投与後より $12 \mathrm{hr}$ 以内に効果を判定し, 次 の結果を得た。

（1）“著効”, “有効”, “やや有効”を併せた単純有 効率（ショック・スコアによる判定）は MP 群の 方が HC 群より優れていた。

(2)有用度評価の分布は MP 群の方が HC 群よ り優れていた。

(3)ショック・スコア, 収縮期血圧, 脈圧, Shock Index, 時間尿量, Base Excess, 動脈血 $\mathrm{pH}$ の改 善は, MP 群の方が HC 群より優れていた.

\section{文 献}

1) Weil M. H., et al.: Shock caused by gram negative microorganism. Ann. Int. Med., 60 : 384-400 (1964).

2) Schumer W.: Steroids in the treatment of clinical septic shock. Ann. Surg., 184 : 333341 (1976).

3) Glenn J.M., et al. : Anti-toxic action of methylprednisolone in hemorrhagenic shock. Eur. J. Pharmacol., 13 : 230-238 (1971).

4) Motsay G. J., et al. : Use of corticosteroids in the treatment of shock. Int. Surg., 59:593600 (1974).

5) Lozman, J. et al. : Cardiopulmonary adjustments following single high dosage administration of methylprednisolone in traumatized man. Ann. Surg., 181 : 317-324 (1975).

6）小川 龍：ショックの定量的評価法一ショッ ク・スコアの提案. 救急医学, $3: 329-332$ (1979).

7) Allgöwer M. et al. : Shockpathogenese und Ihre Differential-diagnose, IM. Shock. und Shockbehandlung. Der Chirurg., $38:$ 97-103 (1967).

8）日本医師会編：臨床検査指針, 金原出版, 東京, 
(1975).

9) Lillehii R. C. et al. : Physiological approach to successful treatment of endotoxin in shock in the experimental animal. Arch. Surg., $78:$ :464-471 (1959).

10) Clermond H.G. : Steroid Effect on the release of the lysosomal enzyme acid phosphatase in shock. Ann. Surg., 179:917-921
(1974).

11) Schumer $W$. et al. : Immunologic mechanisms of corticosteroid in circulating shock steroids and shock. University Park Press, Baltimore, pp. 333 (1974).

12) Schumer W. : Cellular Metabolism in shock. Shock of low and high flow state. Excerpt. Medica., pp. 16-27 (1972). 